\section{Nitrogenous Components of Tracheal Sap}

E. G. Bollard has investigated the composition of the nitrogen fraction of the tracheal sap in apples with the following results (Austral. J. Biol. Sci., 10, $279 ;$ 1957). Organic nitrogenous compounds accounted for most of the nitrogen present. Aspartic acid, asparagine and glutamine were quantitatively the most important compounds; glutamic acid and other amino-acids were also present as well as a peptide-like substance. While apple variety, rootstock or manurial treatment may have had effects on the level of nitrogen in tracheal sap, they seem to have had little effect on the proportions of the nitrogenous compounds present. Through the growing season, however, there was a definite change in the proportions of some of the constituents. The composition of the soluble nitrogen fraction of leaves and fruits showed distinct differences from the composition of tracheal sap.

\section{Egg Rafts of Angler Fish}

THE common European angler fish, Lophius, lays its eggs in long mucoid rafts which float on the surface of the sea as ribbons $2-3 \mathrm{ft}$. wide and $25-30 \mathrm{ft}$. long. In all the related species of which anything is known of the breeding, similar rafts appear to be formed, always with scrolled ends characteristic for the species. This is true of the various batfish, frogfish, goosefish and monkfish of American waters. In a recent paper (Bull. Amer. Mus. Nat. Hist., 114, 333 ; 1958) Miss P. Rasquin has described the structures which produce these egg rafts, the rafts themselves, and the embryology of two species, Antennarius and Histrio, from the Sargasso Sea. In these species the two ovaries are fused in the middorsal line and form together a single tightly scrolled ribbon, with double curvature. There is a single lumen, while the germinal epithelium is only present on the inside surface of the scroll. Tufts project into the lumen, terminating in each branch, during the breeding season, in a ripening ovum. At the time of ovulation the whole epithelium lining the lumen secretes rapidly, during the course of a single day, a mass of mucoid material; then the ova are ovulated into this mass, coming to lie in the spaces in the mass formerly occupied by the tufts. Peristaltic movements of the ovarian wall force the mass out through the cloaca, centre first. There is a rapid intake of water through the pores which represent the spaces occupied in the ovary by the bases of the tufts. In the presence of a courting male the sperm is carried into the raft in this intake of water and fertilization takes place inside the raft. Each egg thus lies free in a separate compartment within the raft in communication with the outside sea-water. The raft itself is an enlarged replica of the internal surfaces of the ovarian lumen. Rafts can be produced with great rapidity, as many as twenty-five being produced in the course of a threemonth breeding season. The early embryology as described in this paper seems very strange and requires further elucidation.

\section{Contemporary Formation of Dolomite}

ONE of the most intriguing problems of sedimentary geology is the mechenism by which the mineral dolomite (the double carbonate, $\mathrm{Ca} . \mathrm{Mg}\left(\mathrm{CO}_{3}\right)_{2}$, as opposed to mixtures or solid solutions of calcium carbonate and magnesium carbonate) is formed in Nature. Dolomite has been an important rock- forming mineral, and with it there are often found typos of fossils which suggest that it was formed in warm, shallow, marine waters. On the other hand, true dolomite has only been found in modern marine sediments in very minor quantities; also, attempts to synthesize the mineral in the laboratory at ordinary temporatures and pressures have so far been unsuccessful. Some fresh light has recently been shed on the problem by A. R. Alderman and H. C. W. Skinner, who describe, in the American Journal of Science $(255,561)$ of October 1957, sediments containing appreciable amounts of dolomite which are being formed to-day in saline lakes in the coastal region near Kingston, South Australia. The occurrence of dolomite in saltpans has been reported before; the particular significance of the present report is that it has been shown that the composition of the lake-water is essentially that of sea-water in various degrees of dilution and concentration, and that the precipitation of crystalline dolomite has been cleariy related with elevation of $p H$ at seasons when plant-growth is especially active. Similar deposits are said to be forming in the Coorong, an attenuated gulf linked to the sea at the mouth of the Murray River. The authors suggest, that the region would repay a more intensive study.

\section{Sulphur Dioxide in Atmospheric Chemistry}

SULPHURIC ACID is a major destructive constituent of smoky fog. It has long been believed that it was produced by oxidation of sulphur dioxide in the atmosphere, but little evidence on the reality of the oxidation was available. The matter has now been clarified by experiments carried out by Chr. E. Junge and T. G. Ryan of the U.S. Air Force Cambridge Research Center, Bedford, Mass. (Quart. J. Roy. Meteor. Soc., 84, 46; 1958). They found that oxidation of sulphur dioxide can occur in dilute solutions in the presence of ammonia. Other substances, for example ferrous chloride, can also act as catalysts but are not found naturally in the atmo. sphere. The process stops after the $p \mathrm{H}$ value in the solution falls to about $\mathbf{2 \cdot 2}$. Reference is also made to unpublished work by E. R. Gerhard showing that sulphur dioxide can be oxidized in the air to sulphur trioxide in strong sunlight without presence of water droplets and ammonia, but no general conclusion can yet be made as to the relative importance of the two processes.

\section{Gairdner Foundation : International Awards}

The Gairdner Charitable Foundation (Ontario), Canada, which was founded in 1957 and derived its funds from personal gifts of Mr. J. A. Gairdner, a Canadian industrialist and financier, and members of his family, has established two international awards, to be made for the first time in 1958: The Gairdner Foundation Award of Merit, a prize of 25,000 dollars to be awarded not more than once every four years to the individual or group of individuals who has made the most outstand. ing discovery or contribution in the fields of the arthritic, rheumatic and cardio-vascular diseases; and The Gairdner Foundation Annual Auards, comprising a series of prizes of 5,000 dollars each to be awarded in any one year to not more than five individuals who have made outstanding discoveries or contributions in the same field. Awards will be made at the discretion of the Foundation and will not be open to application on the part of potential 